\title{
Niche Marketing Strategies: The Role of Special-Purpose Transportation Efforts in Attracting and Retaining Transit Users
}

\author{
J. Joseph Cronin, Jr., Florida State University \\ Roscoe Hightower, Jr., Florida A\&M University \\ Michael K. Brady, Boston College
}

\begin{abstract}
$\overline{\text { Abstract }}$
This study evaluates the use of public transit niche strategies as an alternative marketing strategy designed to attract and retain new public transit riders. Four niche efforts, a university football shuttle, professional football shuttle, summer metropolitan park shuttle, and suburban subscription vanpool are the focus of the investigation. A total of 738 intercepts provide the data for the research. The researchers conclude that niche marketing efforts are an effective strategy, and therefore should be an important tool in the public transit industry's efforts to attract and retain new riders in order to offset the prolonged decline in public transit market share.
\end{abstract}

\section{Introduction}

The perception of public transit as a viable commuting option has steadily declined. Its overall share of the commuting market declined from 3.6 percent in 1969 , to 2.6 percent in 1983, to 2.0 percent in 1990 (Khattak, Noeimi, and Al-Deek 1996; Pisarski 1992). The loss of market share is even more dramatic 
for work commutes where public transit's share declined from 12.6 percent in 1960 to 5.3 percent in 1990 (Khattak, Noeimi, and Al-Deek 1996; Ball 1994). However, the most dramatic evidence of the difficulty public transit has in attracting and retaining riders can be found in metropolitan areas (MSA) where its market share declined by 24.9 percent from 1980 to 1990 while the total number of commute trips made by MSA residents increased by 20.5 percent (Kemp et al. 1997).

In spite of the need for innovative marketing-based solutions, comparatively little attention has been directed to developing a better understanding of how consumer marketing approaches might be utilized by public transit agencies. For example, efforts to identify how to increase product awareness and encourage trial are traditional responses for organizations experiencing a small and declining market share (Jones 1990; Langlois 1986). With consumer products, this is typically done through sampling; that is, the delivery of free, or lowcost, product samples to potential customers. Examples of such strategies can be found almost daily in mailboxes or during trips to local retail stores. Sampling as a marketing strategy is obviously more difficult in the case of public transit. However, there is a lesson to be learned from consumer marketers.

As the cost of delivering product samples to consumers' homes has become almost prohibitive, marketers of consumer products have embraced instore product sampling techniques (Blattberg and Neslin 1990; Boulding, Lee, and Staelin 1992). A visit to a local grocery store or warehouse club provides ample evidence of efforts to bring the product to a central location where large numbers of consumers can "sample" it. Niche market strategies are the public transit equivalent of these efforts. The intent of such strategies is to identify an event, or events, where a great number of people, particularly nontransit users, are in attendance and public transit is a visible, viable, and potentially attractive transportation alternative. Consumers in such situations are provided with an enticement to "sample" transit services, in that by using the service they can 
avoid long waits in traffic, difficult searches for parking, potential damage to their vehicles, and other problems. Transit providers are thereby afforded an opportunity to promote the quality of their services and to use entertainmentbased tactics to elicit a level of satisfaction that will encourage "sample riders" to consider public transit services as an alternative in their day-to-day commutes. Moreover, these services do not have to be given away. Frequently, either the event sponsor or the riders themselves are only too happy to pay for the "convenience" of using such public transit services.

\section{Niche Marketing Strategies}

Niche transit marketing strategies are defined in this article simply as onetime, or infrequently occurring, transit services designed to offer access to a unique event or activity. Common examples include transportation to and from sports events, parades, holiday festivities and activities, seasonal recreational activities, and other similar events and occasions. The service may be offered using fixed or flexible routes, and regular or specially prepared vehicles. For instance, the Orioles' Train was a specially decorated railcar that ran on a fixed route from Washington D.C.'s Union Station to Baltimore's Camden Yards on Orioles' game days. In San Francisco and Chicago, regularly scheduled BART and CTA trains are promoted as a transit option for Oakland As' and Raiders' and Chicago White Sox's games. Many cities also use their transit systems to facilitate transportation to and from Fourth of July and New Year's Eve celebrations, Christmas or Thanksgiving Day parades, and other local festivities. Some also use such services seasonally to move local residents and tourists through parks or to and from other local attractions.

However, to date, the value of these efforts as marketing tools seems to have been largely overlooked by public transit properties. Too often, it appears that such transit services are offered as a "convenience" or "public service" with little consideration of their potential as a marketing tool. In fact, such efforts are 
often criticized as expensive and excessive or even as inappropriate because they appear to be subsidizing the operations of privately held organizations.

The objective of this study is to determine whether niche strategies are, in fact, an effective means to attract and retain new transit customers. That is:

1. Are the users of such services likely to be non- or infrequent public transit users?

2. If they are non- or infrequent public transit users, are they likely to increase their overall transit use as a result of their use of niche services?

3. If niche strategies are an effective means of attracting and retaining transit customers, what determines the service quality perceptions and satisfaction levels of niche transit customers?

The underlying theme investigated is that niche marketing efforts can be positively employed by public transit organizations if they are properly planned and executed as a promotional tactic rather than as a goodwill or community service project.

\section{The Research}

In order to better understand niche transit marketing strategies, four such efforts were investigated $(N=738)$ :

1. college football shuttle service (sample $1 ; n=181$ ),

2. professional football shuttle service (sample $2 ; n=212$ ),

3. summer metropolitan park shuttle service (sample $3 ; n=231$ ), and

4. subscription vanpool service (sample $4 ; n=114$ ).

The four samples were drawn in separate metropolitan areas that have well-established public transit properties. Sample 1 is from a mid-sized southeastern city where the local economy is dominated by multiple state universities and government offices. Sample 2 is drawn from a second, and larger, southeastern city. The area's economy is dominated by service and military 
operations. Samples 3 and 4 are from different, very large, Midwestern cities that have diversified economies. The vanpool subscription service was identified as a niche strategy by the local public transit property based on the fact that it was the only one they operate, it serves a single employer, and was designed to encourage its users to utilize the property's rail and bus services.

Data for each of the samples were collected through personal intercepts at the events identified. Graduate students under the direction of the first author gathered the data in samples 1 and 2 and employees of the local public transit properties were responsible for that task in samples 3 and 4 . The survey instrument utilized was identical for each location with minor variations to account for service differences. Specifically, the survey for sample 3 did not contain four questions that were deemed not applicable by the local transit agency. In addition, one question was added to reflect a unique characteristic of this system. In sample 4, four questions relative to staff performance were eliminated because no local agency staff had contact with users of the service.

Generally, the gender, income, and age distributions of the respondents are similar. The two exceptions are that sample 3 has proportionately more women (about $60 \%$ as compared to $50 \%$ in the other samples) and the college football shuttle program (sample 1) understandably exhibits a slightly younger mix of respondents.

\section{Results}

This section examines the results of the four public transit systems' niche strategies.

\section{Who Uses Public Transit Niche Services?}

The first focal research question is concerned with whether the users of niche services are likely to be non- or infrequent users of public transportation in general. Of the 738 total respondents, 265 (35.9\%) either agree or strongly agree with the statement "I frequently use (the transit agency name) to com- 
mute to work." A total of 256 (34.7\%) either agree or strongly agree with the statement "I frequently use (the transit agency name) for purposes other than work." The implication of these data is that approximately 65 percent of the niche service riders do represent new or infrequent transit users.

\section{Do Niche Strategies Increase Overall Transit Use?}

If 65 percent of the individuals reached by niche services are new or infrequent public transit users, these strategies are increasing the use of public transit in their own right. However, if niche strategies are to be truly effective, the investment in these efforts needs to be leveraged; that is, system operators want these new or infrequent users to become users of other public transit services. The results suggest such is the case. Of the 310 total respondents who indicated that they are new or infrequent users of public transit by not agreeing or strongly agreeing with the statements, "I frequently use (name of local transit system) to commute to work" and "I frequently use (name of local transit system) for purposes other than work," only 19.5 percent expressed a reluctance to "use other similar services."

In contrast, 62.2 percent strongly agreed or agreed that they would be willing to use other public transit services. Among the same group of respondents (i.e., new or infrequent transit users), only 6.5 percent indicated that they would not use the same service again, whereas 76.3 percent strongly agreed or agreed that they would use it again. Thus, the researchers found strong support for the use of niche marketing strategies as a means of attracting and retaining new or infrequent public transit users.

Unfortunately, space on the research instrument and the time available to question respondents limited the researchers' ability to identify what "other similar services" the non- or infrequent riders would use. In order to answer this question, a longitudinal study is needed to track the public transit usage of such individuals. One means to accomplish this is the use of a "diary" study. In this type of research, respondents keep a daily log of their transportation 
activities. An analysis of this information can identify what services are used, how often they are used, when they are used, and for what purpose. Public transit marketers can use such techniques as distributing smart cards that allow an individual's use of a transit system to be tracked. Casino- and airline-like frequency programs are examples of how this technique can be implemented.

\section{What Are the Determinants of the Service Quality Perceptions and}

\section{Customer Satisfaction of Public Transit Niche Marketing Strategies?}

The success of niche marketing strategies is dependent on their ability to elicit three behaviors from customers. These behaviors are customers' willingness to (1) reuse the same service, (2) use other public transit services, and (3) recommend public transit services to other consumers. The mean response of the respondents relative to their willingness to engage in these three behaviors respectively was $4.56,4.07$, and 4.47 (where $1=$ strongly disagree and $5=$ strongly agree). This indicates a strong overall tendency among respondents to react to niche strategies in a manner beneficial to the transit provider. The attendant question is why? The model depicted in Figure 1 suggests the theory underlying the positive response to niche public transit strategies. That is, the high levels of perceived service qual-

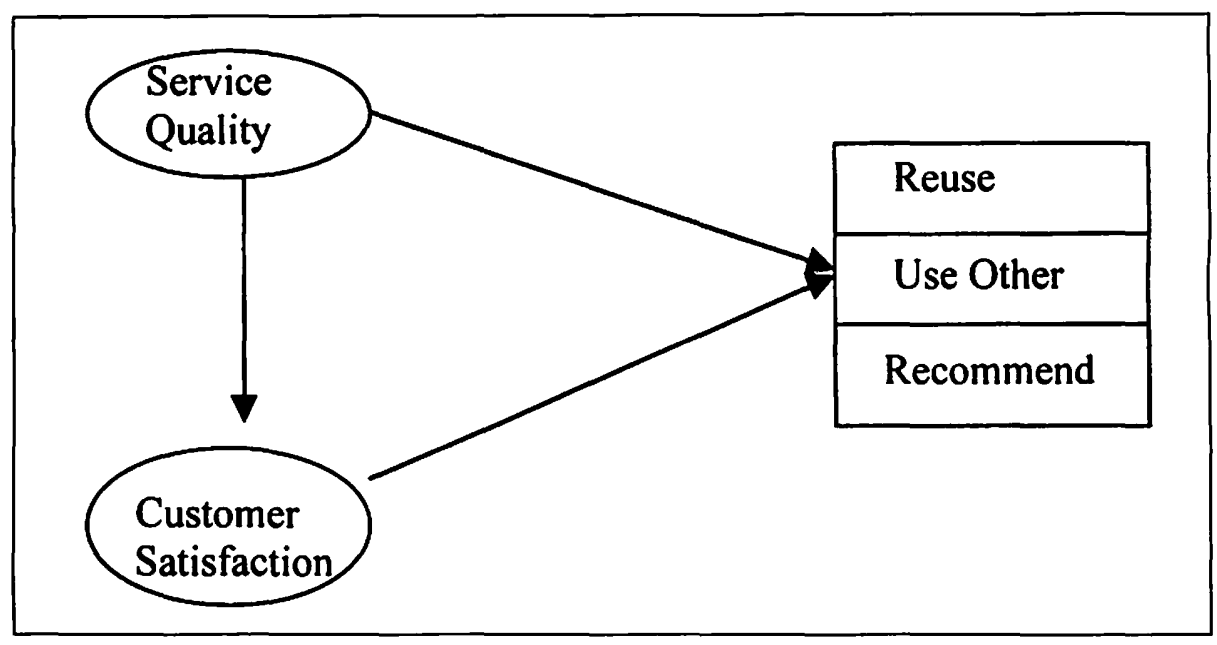

Figure 1. The research model 
ity lead to customer satisfaction and willingness to engage in the desired behaviors-to use and/or recommend other public transit services.

The results identified in Table 1 validate the proposed relationship. Service quality and customer satisfaction exhibit a correlation of .914, indicative of the magnitude of the impact that transit users' perception of the quality of the service received has on their satisfaction with the transit provider. Additionally, these results point out the impact that service quality perceptions and customer satisfaction have on the success of niche marketing strategies by

\begin{tabular}{|c|c|c|c|}
\hline \multicolumn{4}{|c|}{$\begin{array}{c}\text { Table } 1 \\
\begin{array}{c}\text { Perceived Service Quality and Customer Satisfaction Effects } \\
\text { on Behavioral Outcomes }\end{array}\end{array}$} \\
\hline Variable & Beta & t-value & Significance \\
\hline $\begin{array}{l}\text { 1. The quality of the service I received today was } \\
\text { excellent (Perceived Service Quality) }\end{array}$ & .135 & 2.428 & .015 \\
\hline $\begin{array}{l}\text { 2. I am very happy with this service } \\
\text { (Customer Satisfaction) }\end{array}$ & .687 & 12.381 & .000 \\
\hline DV. I would use this service again & & & Adj $R^{2}=.658$ \\
\hline Variable & Beta & $\mathrm{t}$-value & Significance \\
\hline $\begin{array}{l}\text { 1. The quality of the service I received today was } \\
\text { excellent (Perceived Service Quality) }\end{array}$ & .409 & 5.165 & .000 \\
\hline $\begin{array}{l}\text { 2. I am very happy with this service } \\
\text { (Customer Satisfaction) }\end{array}$ & .167 & 2.111 & .035 \\
\hline $\begin{array}{l}\text { DV. Because of this service, I would use other } \\
\text { transit services }\end{array}$ & & & $\operatorname{Adj} R^{2}=.319$ \\
\hline Variable & Beta & $\mathrm{t}$-value & Significance \\
\hline $\begin{array}{l}\text { 1. The quality of the service I received today was } \\
\text { excellent (Perceived Service Quality) }\end{array}$ & .222 & 4.168 & .000 \\
\hline $\begin{array}{l}\text { 2. I am very happy with this service } \\
\text { (Customer Satisfaction) }\end{array}$ & .621 & 11.676 & .000 \\
\hline $\begin{array}{l}\text { DV: I would strongly recommend this service to a } \\
\text { good friend }\end{array}$ & & & Adj $R^{2}=.686$ \\
\hline
\end{tabular}


public transit organizations. Both have a consistently strong, positive, and statistically significant influence on the willingness of consumers to reuse the specific niche service investigated, to use other transit services, and to recommend the public transit services to other consumers.

More specifically, although each has a significant impact on the three behavioral outcomes (see the beta and their respective significance values in Table 1), service quality appears to have a greater influence on transit users' willingness to try other transit services (i.e., its beta and associated $t$-value are greater than those for customer satisfaction). The more emotional-based satisfaction variable appears to have a greater influence on the focal niche service, specifically, in terms of the users' willingness to reuse and recommend the niche service (i.e., the betas and associated $t$-values for customer satisfaction are greater for these dependent variables [DVs]). The more cognitive, or evaluative, service quality assessment in contrast appears to have more influence in extending the impact of the niche marketing effort. That is, the better the perceived performance of a niche public transit strategy, the more likely patrons are to use other services offered by their local transit property. It also suggests that if public transit organizations want a niche marketing strategy to increase the use of their traditional services (i.e., fixed-route rail or bus services), they need to stress and deliver service excellence. Thus, promotions should also emphasize service excellence, and the best operators and equipment available should be utilized.

\section{Impact of Service Quality Perceptions on Behavioral Outcomes}

This study also investigated the effects of niche marketing strategies on three behaviors: customers' willingness to (1) reuse the niche service, (2) use other public transit services, and (3) recommend public transit services. A key assumption that underlies the use of niche strategies is that they help public transit organizations attract and retain users. As indicated above, the majority of the users of the niche transit services investigated are not regular public tran- 
sit customers. Thus, if users indicate a willingness to reuse the service, evidence of the ability of these services to retain, as well as attract, new customers is identified.

The results identified in Table 2 suggest first that service quality perceptions are important as they explain $80.6,66.6,66.9$, and 75.5 percent of the variation in the respondents' intentions to reuse the four investigated public transit services. Overall, the most obvious implication from Table 2 is that the niche public transit users prefer to reuse services that are more convenient than driving themselves (see samples 1,2, and 3). Therefore, an emphasis on communicating the convenience of public transit services is needed in the providers' promotional efforts. More specific details are provided below.

\section{Evaluating Specific Performance Dimensions}

For the major university football shuttle, the respondents appear to prefer a clean, quick, not overly crowded, safe service where there is no waiting and parking is convenient. Users of the professional football shuttle service indicate a preference for quick, convenient service where tickets are easily purchased. The summer metropolitan park shuttle service users indicate that clean vehicles, convenient stops, and a friendly, helpful staff that is available when needed is what gets them to reuse this service. In contrast, the subscription vanpool users suggest that clean and comfortable vehicles, convenient stops, courteous, friendly drivers, and easy ticket availability are the factors that lead them to reuse this service. These factors thereby need to be incorporated into both the operational and marketing (i.e., promotional) efforts of public transit organizations.

\section{Intentions to Use Other Transit Services}

Table 3 identifies the impacts of service quality on the intentions of niche service users to expand their use to other transit services. This also is a test of a key assumption of the value of niche marketing strategies; that is, that they influence users to expand their product usage. The results identified in Table 3 
Table 2

Influence of Individual Service Quality Perceptions on Intentions to Reuse the Service

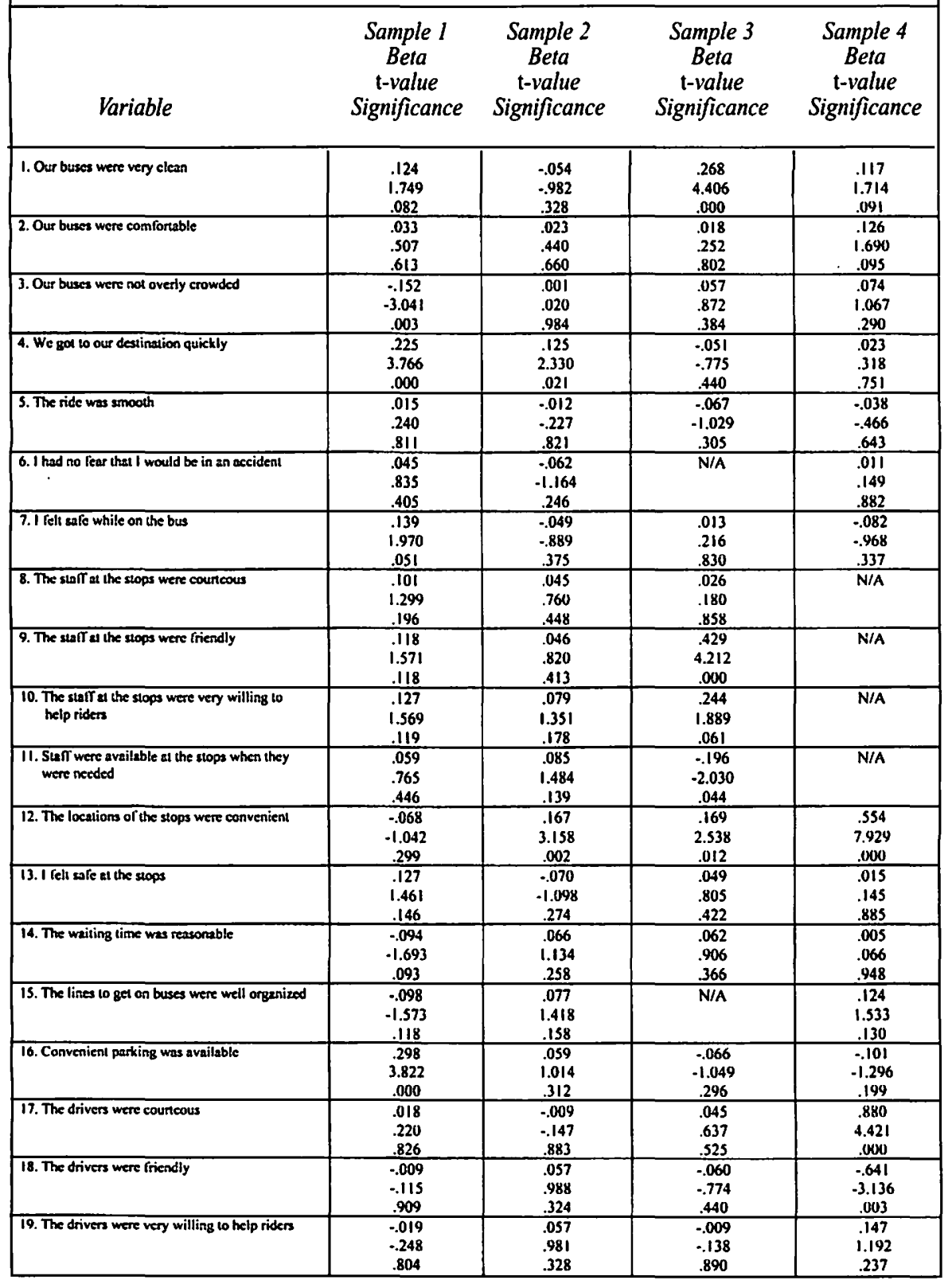




\begin{tabular}{|c|c|c|c|c|}
\hline \multicolumn{5}{|c|}{ Table 2 (continued) } \\
\hline Variable & $\begin{array}{c}\text { Sample l } \\
\text { Beta } \\
\text { t-value } \\
\text { Significance }\end{array}$ & $\begin{array}{c}\text { Sample } 2 \\
\text { Beta } \\
\text { t-value } \\
\text { Significance }\end{array}$ & $\begin{array}{c}\text { Sample } 3 \\
\text { Beta } \\
\text { t-value } \\
\text { Significance }\end{array}$ & $\begin{array}{c}\text { Sample } 4 \\
\text { Beta } \\
\text { t-value } \\
\text { Significance }\end{array}$ \\
\hline 20. II was easy to buy a ticket & $\begin{array}{l}-.030 \\
. .432 \\
.666\end{array}$ & $\begin{array}{l}.367 \\
6.384 \\
.000\end{array}$ & $\begin{array}{l}-.042 \\
-.472 \\
.638\end{array}$ & $\begin{array}{l}.244 \\
2.837 \\
.006\end{array}$ \\
\hline 21. We were well organized & $\begin{array}{l}-.010 \\
-.127 \\
.899\end{array}$ & $\begin{array}{l}.081 \\
1.117 \\
.265\end{array}$ & N/A & $\begin{array}{l}.168 \\
1.628 \\
.108\end{array}$ \\
\hline 22. Einousgh information was avaltable & $\begin{array}{r}-.086 \\
-1.235 \\
.219\end{array}$ & $\begin{array}{l}-.028 \\
-.392 \\
.696\end{array}$ & $\begin{array}{r}-.048 \\
-.691 \\
.491\end{array}$ & $\begin{array}{l}.1 .56 \\
1.846 \\
.069\end{array}$ \\
\hline 23. Convenient parking was available & $\begin{array}{c}-.090 \\
-1.088 \\
.278\end{array}$ & $\begin{array}{l}.002 \\
.040 \\
.968\end{array}$ & $\mathrm{~N} / \mathrm{A}$ & $\begin{array}{l}-.057 \\
-.637 \\
.526\end{array}$ \\
\hline $\begin{array}{l}\text { 24. This service is more convenient than } \\
\text { driving ourselves }\end{array}$ & $\begin{array}{l}.540 \\
7.482 \\
.000\end{array}$ & $\begin{array}{c}.330 \\
5.659 \\
.000\end{array}$ & $\begin{array}{c}.14 ! \\
2.460 \\
.015\end{array}$ & $\begin{array}{l}.090 \\
1.089 \\
.280\end{array}$ \\
\hline 25. The connection with — is converient & $\mathrm{N} / \mathrm{A}$ & N/A & $\begin{array}{c}.209 \\
3.290 \\
.001\end{array}$ & N/A \\
\hline DV: I would use this service again & $\operatorname{ddj} \mathrm{R}^{2}=.816$ & $\operatorname{ddj} \mathrm{R}^{2}=.66 \mathrm{~S}$ & $\operatorname{ddj} \mathrm{R}^{2}=.66 \mathrm{y}$ & $\mathrm{Adj} \mathrm{R}^{2}=.755$ \\
\hline
\end{tabular}

support this assumption as service quality perceptions explain $36.5,31.6,45.1$, and 33.0 percent of the variation in the respondents' intentions to use other transit services.

Individually, users of the university football shuttle service (sample 1) indicate that safety, organization, and convenience are the factors that encourage them to expand their use of transit services beyond the niche effort. Sample 2 users, the professional football shuttle service, suggest that a wellorganized, smooth, uncrowded ride that is more convenient than driving and free of the fear of an accident enhances the probability that they will use other transit services. The summer metropolitan park shuttle service users (sample 3 ) indicate that clean vehicles, safe stops, convenient parking, and links to the local mass transit system will similarly motivate them. The subscription vanpool users (sample 4) suggest that reasonable waiting times, conveniently available tickets, and information availability are the factors that will lead them to expand their use of public transit services.

These results suggest that the factors that encourage niche riders to use other public transit services are not identical to those that lead to reuse of the 
Table 3

\section{Analysis of the Importance of Individual Service Quality Perceptions on Intentions to Use Other Similar Services}

\begin{tabular}{|c|c|c|c|c|}
\hline Variable & $\begin{array}{c}\text { Sample I } \\
\text { Beta } \\
\text { t-value } \\
\text { Significance }\end{array}$ & $\begin{array}{c}\text { Sample } 2 \\
\text { Beta } \\
\text { t-value } \\
\text { Significance }\end{array}$ & $\begin{array}{c}\text { Sample } 3 \\
\text { Beta } \\
\text { t-value } \\
\text { Significance }\end{array}$ & $\begin{array}{c}\text { Sample } 4 \\
\text { Beta } \\
\text { t-value } \\
\text { Significance }\end{array}$ \\
\hline T. Our buses were very clean & $\begin{array}{l}.102 \\
.479 \\
.633 \\
\end{array}$ & $\begin{array}{r}.121 \\
1.119 \\
.265 \\
\end{array}$ & $\begin{array}{r}.480 \\
5.096 \\
.000 \\
\end{array}$ & $\begin{array}{l}.129 \\
.672 \\
.505 \\
\end{array}$ \\
\hline 2. Our buses were confortable & $\begin{array}{l}.202 \\
.980 \\
.329 \\
\end{array}$ & $\begin{array}{r}.137 \\
1.319 \\
.189 \\
\end{array}$ & $\begin{array}{r}.120 \\
1.090 \\
.278 \\
\end{array}$ & $\begin{array}{l}.134 \\
.572 \\
.570 \\
\end{array}$ \\
\hline 3. Our buses were not overly crowded & $\begin{array}{l}.015 \\
.136 \\
.892 \\
\end{array}$ & $\begin{array}{r}.195 \\
2.538 \\
.012 \\
\end{array}$ & $\begin{array}{l}.067 \\
.693 \\
.489 \\
\end{array}$ & $\begin{array}{l}.034 \\
.180 \\
.858 \\
\end{array}$ \\
\hline 4. We got to our destination quickly & $\begin{array}{l}.031 \\
.194 \\
.846\end{array}$ & $\begin{array}{r}.126 \\
1.353 \\
.178\end{array}$ & $\begin{array}{l}.032 \\
.304 \\
.761\end{array}$ & $\begin{array}{l}.061 \\
.254 \\
.801 \\
\end{array}$ \\
\hline 5. The ride was smooth & $\begin{array}{l}.080 \\
.513 \\
.609\end{array}$ & $\begin{array}{r}.283 \\
2.370 \\
.019 \\
\end{array}$ & $\begin{array}{l}.097 \\
.993 \\
.323 \\
\end{array}$ & $\begin{array}{l}.098 \\
.366 \\
.715 \\
\end{array}$ \\
\hline 6. I had no lear that I would be in an accident & $\begin{array}{r}.174 \\
1.150 \\
.252\end{array}$ & $\begin{array}{r}.219 \\
1.835 \\
.068 \\
\end{array}$ & N/A & $\begin{array}{l}.262 \\
.551 \\
.584 \\
\end{array}$ \\
\hline 7. I lelt safe while on the bus & $\begin{array}{r}.371 \\
1.808 \\
.073 \\
\end{array}$ & $\begin{array}{r}.175 \\
1.224 \\
.223 \\
\end{array}$ & $\begin{array}{l}.063 \\
.610 \\
.543 \\
\end{array}$ & $\begin{array}{l}.160 \\
.357 \\
.722 \\
\end{array}$ \\
\hline 8. The staff al the stops were courtcous & $\begin{array}{l}.121 \\
.400 \\
.690\end{array}$ & $\begin{array}{r}.150 \\
.780 \\
.437\end{array}$ & $\begin{array}{r}.309 \\
1.415 \\
.159\end{array}$ & N/A \\
\hline 9. The staff at the stops were friendly & $\begin{array}{l}.181 \\
.461 \\
.646\end{array}$ & $\begin{array}{r}.209 \\
1.061 \\
.290\end{array}$ & $\begin{array}{l}.220 \\
.942 \\
.348\end{array}$ & N/A \\
\hline $\begin{array}{l}\text { 10. The staft at the stops were very willing to help } \\
\text { riders }\end{array}$ & $\begin{array}{l}.035 \\
.096 \\
.924\end{array}$ & $\begin{array}{l}.074 \\
.474 \\
.636\end{array}$ & $\begin{array}{l}.104 \\
.470 \\
.639\end{array}$ & N/A \\
\hline $\begin{array}{l}\text { 11. Stall were available at the stops when they } \\
\text { were needed }\end{array}$ & $\begin{array}{l}.208 \\
.694 \\
.489\end{array}$ & $\begin{array}{l}.109 \\
.745 \\
.458\end{array}$ & $\begin{array}{l}.062 \\
.417 \\
.677\end{array}$ & N/A \\
\hline 12. The locations of the stops were convenient & $\begin{array}{l}.106 \\
.672 \\
.502\end{array}$ & $\begin{array}{r}.122 \\
1.195 \\
.234\end{array}$ & $\begin{array}{r}.194 \\
1.532 \\
.128\end{array}$ & $\begin{array}{l}.026 \\
.116 \\
.908\end{array}$ \\
\hline 13. I lelt safe at the stops & $\begin{array}{l}.151 \\
.654 \\
.514\end{array}$ & $\begin{array}{l}.080 \\
.674 \\
.502\end{array}$ & $\begin{array}{r}.311 \\
3.094 \\
.002\end{array}$ & $\begin{array}{l}.144 \\
.663 \\
.510\end{array}$ \\
\hline 14. The waiting time was reasonable & $\begin{array}{r}.129 \\
1.066 \\
.288\end{array}$ & $\begin{array}{l}.004 \\
.040 \\
.968\end{array}$ & $\begin{array}{l}.047 \\
.449 \\
.654\end{array}$ & $\begin{array}{r}.423 \\
1.977 \\
.053 \\
\end{array}$ \\
\hline 15. The lines to get on buses were well organized & $\begin{array}{l}.201 \\
.702 \\
.484\end{array}$ & $\begin{array}{l}.070 \\
.512 \\
.609\end{array}$ & $N / A$ & $\begin{array}{r}.399 \\
1.178 \\
.244 \\
\end{array}$ \\
\hline 16. Convenient parking was available & $\begin{array}{l}.083 \\
.355 \\
.723\end{array}$ & $\begin{array}{l}.058 \\
.464 \\
.643\end{array}$ & $\begin{array}{r}215 \\
2.119 \\
.036\end{array}$ & $\begin{array}{l}.038 \\
.137 \\
.891\end{array}$ \\
\hline 17. The drivers were courtcous & $\begin{array}{l}.245 \\
.570 \\
.569\end{array}$ & $\begin{array}{l}.010 \\
.050 \\
.960\end{array}$ & $\begin{array}{l}.009 \\
.049 \\
.961\end{array}$ & $\begin{array}{r}.504 \\
1.206 \\
.233\end{array}$ \\
\hline 18. The drivers were friendly & $\begin{array}{l}.276 \\
.586 \\
\end{array}$ & $\begin{array}{l}.125 \\
.578 \\
\end{array}$ & $\begin{array}{r}.301 \\
1.485 \\
\end{array}$ & $\begin{array}{l}.323 \\
.783 \\
\end{array}$ \\
\hline
\end{tabular}




\begin{tabular}{|c|c|c|c|c|}
\hline \multicolumn{5}{|c|}{ Table 3 (continued) } \\
\hline Variable & $\begin{array}{c}\text { Sample I } \\
\text { Beta } \\
\text { t-value } \\
\text { Significance }\end{array}$ & $\begin{array}{c}\text { Sample } 2 \\
\text { Beta } \\
\text { t-value } \\
\text { Significance }\end{array}$ & $\begin{array}{c}\text { Sample } 3 \\
\text { Beta } \\
\text { t-value } \\
\text { Significance }\end{array}$ & $\begin{array}{c}\text { Sample } 4 \\
\text { Beta } \\
\text { t-value } \\
\text { Significance }\end{array}$ \\
\hline 19. The drivers were very willing to help riders & $\begin{array}{r}.572 \\
1.590 \\
.114\end{array}$ & $\begin{array}{l}.001 \\
.009 \\
.993\end{array}$ & $\begin{array}{l}.096 \\
.649 \\
.518 \\
\end{array}$ & $\begin{array}{l}.177 \\
.733 \\
.467\end{array}$ \\
\hline 20. It was easy to buy a ticket & $\begin{array}{r}.285 \\
1.373 \\
.172\end{array}$ & $\begin{array}{l}.020 \\
.166 \\
.869\end{array}$ & $\begin{array}{r}.157 \\
1.045 \\
.298\end{array}$ & $\begin{array}{r}.423 \\
1.649 \\
.105\end{array}$ \\
\hline 21. We were well organized & $\begin{array}{r}.301 \\
4.575 \\
.000 \\
\end{array}$ & $\begin{array}{r}.163 \\
4.716 \\
.000 \\
\end{array}$ & N/A & $\begin{array}{l}.010 \\
.127 \\
.899 \\
\end{array}$ \\
\hline 22. Enough information was available & $\begin{array}{l}.127 \\
.735 \\
.463\end{array}$ & $\begin{array}{l}.119 \\
.819 \\
.414\end{array}$ & $\begin{array}{r}.120 \\
1.037 \\
.302\end{array}$ & $\begin{array}{r}.574 \\
1.644 \\
.106\end{array}$ \\
\hline 23. Convenienl parking was available & $\begin{array}{l}.096 \\
.390 \\
.697 \\
\end{array}$ & $\begin{array}{r}.192 \\
1.296 \\
.197 \\
\end{array}$ & $\mathrm{~N} / \mathrm{A}$ & $\begin{array}{l}.218 \\
.454 \\
.652 \\
\end{array}$ \\
\hline $\begin{array}{l}\text { 24. This service is more convenient than driving } \\
\text { ourselves }\end{array}$ & $\begin{array}{r}.318 \\
1.666 \\
.098\end{array}$ & $\begin{array}{l}.034 \\
.357 \\
.721\end{array}$ & $\begin{array}{l}.051 \\
.669 \\
.505\end{array}$ & $\begin{array}{l}.058 \\
.908 \\
.368\end{array}$ \\
\hline 25. The connection with __ is convenient & $\mathrm{N} / \mathrm{A}$ & N/A & $\begin{array}{r}.199 \\
1.888 \\
.061\end{array}$ & $\mathrm{~N} / \mathrm{A}$ \\
\hline DV: I intend to use other similar services & $\operatorname{Adj} R^{2}=.365$ & $\operatorname{Adj} R^{\prime}=.316$ & $\operatorname{Adj} R^{\prime}=.451$ & $\operatorname{Adj} R^{2}=.33(1)$ \\
\hline
\end{tabular}

niche service. Thus, public transit marketers must employ different messages if this is their objective. Organization, safety, and security join convenience as factors that encourage niche riders to use other public transit services.

\section{Willingness to Recommend Transit Services}

Table 4 provides support for the notion that service quality perceptions play an important role in eliciting positive word-of-mouth, or recommendations, for their public transit properties as they explain 81.9, 69.7, 74.9, and 74.3 percent of the variation in the respondents' willingness to recommend the service to a good friend. Once again, services that consumers view as more convenient than driving themselves register strong support (see samples 1,2 , 3 , and 4).

On a sample-to-sample basis, for the major university football shuttle, respondents express the greatest willingness to recommend the service when it is quick, safe, and convenient. For the professional football shuttle, the will- 


\section{Table 4 \\ Influence of Individual Service Quality Perceptions on Willingness to Recommend this Service}

\begin{tabular}{|c|c|c|c|c|}
\hline Variable & $\begin{array}{c}\text { Sample I } \\
\text { Beta } \\
\text { t-value } \\
\text { Significance }\end{array}$ & $\begin{array}{c}\text { Sample } 2 \\
\text { Beta } \\
\text { t-value } \\
\text { Significance }\end{array}$ & $\begin{array}{c}\text { Sample } 3 \\
\text { Beta } \\
\text { t-value } \\
\text { Significance }\end{array}$ & $\begin{array}{c}\text { Sample } 4 \\
\text { Beta } \\
\text { t-value } \\
\text { Significance }\end{array}$ \\
\hline 1. Our buses were very clean & $\begin{array}{r}-.036 \\
-.481 \\
.631 \\
\end{array}$ & $\begin{array}{r}. .018 \\
-.335 \\
.738 \\
\end{array}$ & $\begin{array}{r}.153 \\
2.770 \\
.006 \\
\end{array}$ & $\begin{array}{r}-.056 \\
-.741 \\
.461 \\
\end{array}$ \\
\hline 2. Our buses were comfortable & $\begin{array}{r}-.106 \\
-1.632 \\
.105 \\
\end{array}$ & $\begin{array}{r}.099 \\
1.833 \\
.068 \\
\end{array}$ & $\begin{array}{r}.007 \\
.102 \\
.919 \\
\end{array}$ & $\begin{array}{r}.132 \\
1.719 \\
.090 \\
\end{array}$ \\
\hline 3. Our buses were not overly crowded & $\begin{array}{r}-.091 \\
-1.859 \\
.065 \\
\end{array}$ & $\begin{array}{l}.033 \\
.682 \\
.496 \\
\end{array}$ & $\begin{array}{r}.139 \\
2.258 \\
.025 \\
\end{array}$ & $\begin{array}{r}.080 \\
1.121 \\
.266 \\
\end{array}$ \\
\hline 4. Wo got to our destination quickly & $\begin{array}{r}.141 \\
2.225 \\
.026 \\
\end{array}$ & $\begin{array}{r}.178 \\
3.250 \\
.001 \\
\end{array}$ & $\begin{array}{r}. .005 \\
-.073 \\
.942 \\
\end{array}$ & $\begin{array}{r}.094 \\
1.308 \\
.195 \\
\end{array}$ \\
\hline S. The ride was smooth & $\begin{array}{r}.091 \\
-1.319 \\
.189\end{array}$ & $\begin{array}{r}.155 \\
3.062 \\
.003 \\
\end{array}$ & $\begin{array}{r}-.108 \\
-1.793 \\
.075 \\
\end{array}$ & $\begin{array}{l}.082 \\
.978 \\
.331 \\
\end{array}$ \\
\hline 6. I had no fear chas I would be in an accident & $\begin{array}{r}-.130 \\
-1.837 \\
.068 \\
\end{array}$ & $\begin{array}{r}.109 \\
1.915 \\
.057 \\
\end{array}$ & N/A & $\begin{array}{l}.054 \\
.658 \\
.513 \\
\end{array}$ \\
\hline 7.1 felt safe while on che bus & $\begin{array}{r}.182 \\
2.472 \\
.015\end{array}$ & $\begin{array}{r}-.087 \\
-1.293 \\
.198\end{array}$ & $\begin{array}{r}.095 \\
1.555 \\
.122\end{array}$ & $\begin{array}{l}.035 \\
.399 \\
.691 \\
\end{array}$ \\
\hline 8. The ateff al the stops were countoous & $\begin{array}{r}. .052 \\
. .436 \\
.663 \\
\end{array}$ & $\begin{array}{r}.059 \\
1.096 \\
.274 \\
\end{array}$ & $\begin{array}{r}.011 \\
.0884 \\
.933 \\
\end{array}$ & N/A \\
\hline 9. The staff at the stopa were friencly & $\begin{array}{l}.037 \\
.257 \\
.797 \\
\end{array}$ & $\begin{array}{l}.046 \\
.843 \\
.400 \\
\end{array}$ & $\begin{array}{r}.645 \\
5.371 \\
3.073 \\
\end{array}$ & N/A \\
\hline $\begin{array}{l}\text { 10. The utalf as the slops were very willing to } \\
\text { help riders }\end{array}$ & $\begin{array}{l}.122 \\
1.453 \\
.148 \\
\end{array}$ & $\begin{array}{l}.028 \\
.503 \\
.616 \\
\end{array}$ & $\begin{array}{r}. .075 \\
-.790 \\
.431 \\
\end{array}$ & N/A \\
\hline $\begin{array}{l}\text { 11. Staff were available at the stops when they } \\
\text { were needed }\end{array}$ & $\begin{array}{r}.090 \\
.826 \\
.410\end{array}$ & $\begin{array}{r}.054 \\
1.030 \\
.305 \\
\end{array}$ & $\begin{array}{r}.088 \\
1.084 \\
.280 \\
\end{array}$ & N/A \\
\hline 12. The locations of the stops were convenient & $\begin{array}{r}-.162 \\
-2.521 \\
.013\end{array}$ & $\begin{array}{r}.100 \\
1.811 \\
.072\end{array}$ & $\begin{array}{r}.088 \\
1.084 \\
.280\end{array}$ & $\begin{array}{r}.148 \\
1.836 \\
.071\end{array}$ \\
\hline 13. I fell safo at the stops & $\begin{array}{l}.004 \\
.040 \\
.968 \\
\end{array}$ & $\begin{array}{r}.111 \\
1.763 \\
.080 \\
\end{array}$ & $\begin{array}{r}.197 \\
3.190 \\
.002 \\
\end{array}$ & $\begin{array}{r}.101 \\
1.178 \\
.243 \\
\end{array}$ \\
\hline 14. The waiting time was reasonsble & $\begin{array}{r}-.023 \\
-.425 \\
.671 \\
\end{array}$ & $\begin{array}{l}.014 \\
.259 \\
.796 \\
\end{array}$ & $\begin{array}{r}.220 \\
-3.334 \\
.001 \\
\end{array}$ & $\begin{array}{r}. .012 \\
-.131 \\
.896 \\
\end{array}$ \\
\hline 15. The lines to get on buses were well orgentized & $\begin{array}{r}. .049 \\
. .837 \\
.404 \\
\end{array}$ & $\begin{array}{l}.036 \\
.664 \\
.508 \\
\end{array}$ & N/A & $\begin{array}{r}.169 \\
1.956 \\
.055 \\
\end{array}$ \\
\hline 16. Convenient parking was availeble & $\begin{array}{r}.191 \\
2.207 \\
.029 \\
\end{array}$ & $\begin{array}{r}.185 \\
3.730 \\
.000 \\
\end{array}$ & $\begin{array}{r}. .118 \\
-1.908 \\
.058 \\
\end{array}$ & $\begin{array}{r}-.231 \\
-2.009 \\
.048 \\
\end{array}$ \\
\hline 17. The drivers were courteous & $\begin{array}{l}. .029 \\
. .352 \\
.725\end{array}$ & $\begin{array}{r}-.010 \\
. .190 \\
.850\end{array}$ & $\begin{array}{r}.276 \\
2.555 \\
.012\end{array}$ & $\begin{array}{r}-.136 \\
-1.207 \\
.232\end{array}$ \\
\hline 18. The drivers were friendly & $\begin{array}{l}-.025 \\
-.326 \\
.745 \\
\end{array}$ & $\begin{array}{r}. .027 \\
. .502 \\
.616 \\
\end{array}$ & $\begin{array}{r}-.799 \\
-6.440 \\
.000\end{array}$ & $\begin{array}{r}-.156 \\
-1.303 \\
.197\end{array}$ \\
\hline 19. The drivers were very willing to help riders & $\begin{array}{r}-.030 \\
. .403 \\
.687 \\
\end{array}$ & $\begin{array}{r}.058 \\
1.072 \\
.285\end{array}$ & $\begin{array}{l}.046 \\
.479 \\
.633 \\
\end{array}$ & $\begin{array}{r}.316 \\
3.609 \\
.001\end{array}$ \\
\hline 20. II was casy to buy a ticket & $\begin{array}{c}.071 \\
-1.1016 \\
.311\end{array}$ & $\begin{array}{r}-.094 \\
-1.415 \\
.159\end{array}$ & $\begin{array}{r}-.493 \\
-5.221 \\
.000\end{array}$ & $\begin{array}{l}.062 \\
.621 \\
.537\end{array}$ \\
\hline
\end{tabular}

Vol. 3, No. 3, 2000 


\begin{tabular}{|c|c|c|c|c|}
\hline \multicolumn{5}{|c|}{ Table 4 (continued) } \\
\hline Variable & $\begin{array}{c}\text { Sample I } \\
\text { Beta } \\
\text { t-value } \\
\text { Significance }\end{array}$ & $\begin{array}{c}\text { Sample } 2 \\
\text { Beta } \\
\text { t-value } \\
\text { Significance }\end{array}$ & $\begin{array}{c}\text { Sample } 3 \\
\text { Beta } \\
\text { t-value } \\
\text { Significance }\end{array}$ & $\begin{array}{c}\text { Sample } 4 \\
\text { Beta } \\
\text { t-value } \\
\text { Significance }\end{array}$ \\
\hline 21. We were well organized & $\begin{array}{l}.055 \\
.669 \\
.504\end{array}$ & $\begin{array}{r}.134 \\
2.288 \\
.023\end{array}$ & N/A & $\begin{array}{r}.459 \\
3.750 \\
.000\end{array}$ \\
\hline 22. Enough informetion was available & $\begin{array}{l}-.003 \\
-.049 \\
.961\end{array}$ & $\begin{array}{r}-.038 \\
-.310 \\
.192\end{array}$ & $\begin{array}{r}-.077 \\
-1.011 \\
.314\end{array}$ & $\begin{array}{l}.002 \\
.012 \\
.991\end{array}$ \\
\hline 23. Convenient parking was available & $\begin{array}{l}.002 \\
.026 \\
.979\end{array}$ & $\begin{array}{l}.004 \\
.053 \\
.958\end{array}$ & $\mathrm{~N} / \mathrm{A}$ & $\begin{array}{l}.050 \\
.417 \\
.678\end{array}$ \\
\hline $\begin{array}{l}\text { 24. This service is more convenient than driving } \\
\text { ourselves }\end{array}$ & $\begin{array}{r}.482 \\
6.330 \\
.000\end{array}$ & $\begin{array}{r}.401 \\
7.242 \\
.000\end{array}$ & $\begin{array}{r}.164 \\
3.179 \\
.002\end{array}$ & $\begin{array}{r}.399 \\
3.944 \\
.000\end{array}$ \\
\hline 25. The connection with __ is convenienl & $\mathrm{N} / \mathrm{A}$ & N/A & $\begin{array}{c}.209 \\
3.29 \\
.001\end{array}$ & $\mathrm{~N} / \mathrm{A}$ \\
\hline $\begin{array}{l}\text { DV: I srongly recommend his service to a good } \\
\text { Friend }\end{array}$ & $\operatorname{ddj} \mathrm{R}^{2}=.8 / 9$ & $\operatorname{Adj} \mathrm{R}^{\prime}=.697$ & $\operatorname{Adj} \mathrm{R}^{2}=.744$ & $\operatorname{Adj} \mathrm{R}^{2}=.743$ \\
\hline
\end{tabular}

ingness to recommend was strongly associated with a quick, convenient, and organized service that featured a smooth ride. For the summer metropolitan park shuttle service, a greater number of factors determined the willingness of users to recommend the service. Clean, convenient, and safe service that featured little waiting, no crowding, and courteous and friendly drivers were the specific factors identified as antecedents of the willingness to recommend the service to others. Users of the subscription vanpool indicated comfortable vehicles, convenient stops, organized service, and courteous and helpful drivers are the factors that lead them to recommend this service. Again, incorporating these implications into marketing efforts allows public transit organizations to leverage their investments in niche marketing strategies.

\section{Impact of Service Quality Perceptions on Customer Satisfaction}

Another important consideration is the impact of transit users' perceptions of the quality of the service they receive. The results identified in Table 5 indicate that much of the variation in customer satisfaction is explained by their perceptions of the quality of the service they receive; specifically, 94.5, 81.5, 74.9, and 82.1 percent, respectively, in the four individual research samples. Interestingly, the service factor that is most often significant across the four 


\begin{tabular}{|c|c|c|c|c|}
\hline \multicolumn{5}{|c|}{$\begin{array}{c}\text { Table } 5 \\
\text { Influence of Individual Service Quality } \\
\text { on Satisfaction with Service }\end{array}$} \\
\hline Variable & $\begin{array}{l}\text { Sample } 1 \\
\text { Beta } \\
\text { t-value } \\
\text { Significance }\end{array}$ & $\begin{array}{l}\text { Sample } 2 \\
\text { Beta } \\
\text { t-value } \\
\text { Significance }\end{array}$ & $\begin{array}{c}\text { Sample } 3 \\
\text { Beta } \\
\text { t-value } \\
\text { Significance }\end{array}$ & $\begin{array}{l}\text { Sample } 4 \\
\text { Beta } \\
\text { t-value } \\
\text { Significance }\end{array}$ \\
\hline 1. Our buses were very clezn & $\begin{array}{r}.127 \\
3.170 \\
.002 \\
\end{array}$ & $\begin{array}{r}.027 \\
. .618 \\
.537\end{array}$ & $\begin{array}{r}.076 \\
1.450 \\
.149\end{array}$ & $\begin{array}{l}.010 \\
.155 \\
.877\end{array}$ \\
\hline 2. Our buses were confortable & $\begin{array}{r}.031 \\
.712 \\
.478 \\
\end{array}$ & $\begin{array}{l}.042 \\
.969 \\
.334 \\
\end{array}$ & $\begin{array}{r}.093 \\
.1 .599 \\
.112 \\
\end{array}$ & $\begin{array}{r}.083 \\
1.111 \\
.270 \\
\end{array}$ \\
\hline 3. Our buses were not overly crowded & $\begin{array}{r}. .026 \\
.952 \\
.343\end{array}$ & $\begin{array}{l}.008 \\
.209 \\
.835\end{array}$ & $\begin{array}{r}-.087 \\
-1.491 \\
.138\end{array}$ & $\begin{array}{l}.024 \\
.386 \\
.701\end{array}$ \\
\hline 4. We got to our destination quickly & $\begin{array}{r}.078 \\
2.170 \\
.031\end{array}$ & $\begin{array}{r}.108 \\
2.447 \\
.015\end{array}$ & $\begin{array}{r}-.160 \\
-2.700 \\
.008\end{array}$ & $\begin{array}{l}.006 \\
.102 \\
.919\end{array}$ \\
\hline S. The ride was smooth & $\begin{array}{l}.000 \\
.002 \\
.909\end{array}$ & $\begin{array}{l}.003 \\
.061 \\
.952 \\
\end{array}$ & $\begin{array}{l}. .034 \\
.596 \\
.552\end{array}$ & $\begin{array}{l}.025 \\
.345 \\
.731 \\
\end{array}$ \\
\hline 6. I hiad no feer thal I would be in an accident & $\begin{array}{l}.022 \\
.553 \\
.581\end{array}$ & $\begin{array}{r}.086 \\
2.064 \\
.040\end{array}$ & N/A & $\begin{array}{r}.102 \\
1.083 \\
.283 \\
\end{array}$ \\
\hline 7.1 feli safe while on the bus & $\begin{array}{r}.114 \\
2.850 \\
.005\end{array}$ & $\begin{array}{r}. .102 \\
.1 .068 \\
.097\end{array}$ & $\begin{array}{r}.290 \\
4.883 \\
.000\end{array}$ & $\begin{array}{r}-.153 \\
-2.148 \\
.035\end{array}$ \\
\hline 8. The staff at the stops were courtoous & $\begin{array}{r}.039 \\
. .857 \\
.393 \\
\end{array}$ & $\begin{array}{r}.182 \\
3.003 \\
.003 \\
\end{array}$ & $\begin{array}{r}.094 \\
-1.267 \\
.207\end{array}$ & N/A \\
\hline 9. The stoff at the stops were friendly & $\begin{array}{r}.048 \\
.1 .035 \\
.302\end{array}$ & $\begin{array}{l}.006 \\
.069 \\
.945 \\
\end{array}$ & $\begin{array}{r}. .026 \\
.341 \\
.734 \\
\end{array}$ & $\mathrm{~N} / \mathrm{A}$ \\
\hline $\begin{array}{l}\text { 10. The stafl at the stops were very willing to help } \\
\text { riders }\end{array}$ & $\begin{array}{r}-.026 \\
-.527 \\
.599\end{array}$ & $\begin{array}{r}-.134 \\
.2 .163 \\
.032\end{array}$ & $\begin{array}{r}-.020 \\
-.283 \\
.778\end{array}$ & N/A \\
\hline $\begin{array}{l}\text { 11. Staff were available al the stops when they } \\
\text { were needed }\end{array}$ & $\begin{array}{r}.009 \\
. .195 \\
.846\end{array}$ & $\begin{array}{l}.046 \\
.636 \\
.526\end{array}$ & $\begin{array}{r}-.079 \\
-1.223 \\
.223\end{array}$ & N/A \\
\hline 12. The locetions of the stops were convenient & $\begin{array}{l}.018 \\
. .509 \\
.612\end{array}$ & $\begin{array}{l}.044 \\
.941 \\
.348\end{array}$ & $\begin{array}{r}.192 \\
3.251 \\
.001\end{array}$ & $\begin{array}{r}.089 \\
1.233 \\
.222\end{array}$ \\
\hline 13.1 felt safe at the stops & $\begin{array}{c}-.097 \\
-1.950 \\
.053\end{array}$ & $\begin{array}{r}-.070 \\
.1 .392 \\
.160\end{array}$ & $\begin{array}{r}.104 \\
1.859 \\
.065\end{array}$ & $\begin{array}{r}. .049 \\
. .626 \\
.534\end{array}$ \\
\hline 14. The waiting time was reasonable & $\begin{array}{r}.049 \\
-1.691 \\
.093\end{array}$ & $\begin{array}{r}.131 \\
3.079 \\
.002\end{array}$ & $\begin{array}{l}.015 \\
.248 \\
.804\end{array}$ & $\begin{array}{r}-.122 \\
-1.607 \\
.113\end{array}$ \\
\hline 15. The lines lo get on buses were well orgenized & $\begin{array}{r}.012 \\
. .364 \\
.716\end{array}$ & $\begin{array}{l}.028 \\
.522 \\
.602\end{array}$ & N/A & $\begin{array}{r}.243 \\
3.340 \\
.001\end{array}$ \\
\hline 16. Convenient perking was availzble & $\begin{array}{r}.157 \\
3.612 \\
.000 \\
\end{array}$ & $\begin{array}{r}.120 \\
2.276 \\
.024 \\
\end{array}$ & $\begin{array}{r}.037 \\
. .639 \\
.524 \\
\end{array}$ & $\begin{array}{r}-.096 \\
-1.248 \\
.216 \\
\end{array}$ \\
\hline 17. The drivers were courteous & $\begin{array}{l}.001 \\
.012 \\
.990 \\
\end{array}$ & $\begin{array}{l}.010 \\
.140 \\
.889 \\
\end{array}$ & $\begin{array}{r}.257 \\
4.626 \\
.000 \\
\end{array}$ & $\begin{array}{l}.083 \\
.880 \\
.382 \\
\end{array}$ \\
\hline 18. The drivers were friendly & $\begin{array}{r}.013 \\
-.724 \\
.470 \\
\end{array}$ & $\begin{array}{l}.002 \\
.027 \\
.978\end{array}$ & $\begin{array}{r}.044 \\
. .410 \\
.682\end{array}$ & $\begin{array}{l}.090 \\
.920 \\
.361\end{array}$ \\
\hline 19. The drivers were very willing to help riders & $\begin{array}{l}.029 \\
.633 \\
.528 \\
\end{array}$ & $\begin{array}{r}146 \\
2.993 \\
.003 \\
\end{array}$ & $\begin{array}{l}.001 \\
.009 \\
.992 \\
\end{array}$ & $\begin{array}{r}.269 \\
3.447 \\
.001\end{array}$ \\
\hline 20. If was casy to buy a ticket & $\begin{array}{c}. .014 \\
. .258 \\
.797\end{array}$ & $\begin{array}{l}.030 \\
.510 \\
.611\end{array}$ & $\begin{array}{r}.075 \\
1.015 \\
.312 \\
\end{array}$ & $\begin{array}{r}.139 \\
1.754 \\
.084\end{array}$ \\
\hline
\end{tabular}




\begin{tabular}{|c|c|c|c|c|}
\hline Variable & $\begin{array}{c}\text { Sample 1 } \\
\text { Beta } \\
\text { t-value } \\
\text { Significance }\end{array}$ & $\begin{array}{c}\text { Sample } 2 \\
\text { Beta } \\
\text { t-value } \\
\text { Significance }\end{array}$ & $\begin{array}{c}\text { Sample } 3 \\
\text { Beta } \\
\text { t-value } \\
\text { Significance }\end{array}$ & $\begin{array}{c}\text { Sample } 4 \\
\text { Beta } \\
\text { t-value } \\
\text { Significance }\end{array}$ \\
\hline 21. We were well organized & $\begin{array}{r}.125 \\
2.565 \\
.011\end{array}$ & $\begin{array}{r}.169 \\
2.838 \\
.005\end{array}$ & N/A & $\begin{array}{r}.402 \\
4.082 \\
.000\end{array}$ \\
\hline 22. Finough information was avzilsble & $\begin{array}{r}.104 \\
2.448 \\
.015\end{array}$ & $\begin{array}{r}169 \\
2.838 \\
.005\end{array}$ & $\begin{array}{r}.097 \\
1.621 \\
.107\end{array}$ & $\begin{array}{r}-.001 \\
.008 \\
.0994\end{array}$ \\
\hline 23. Convenient parking was available & $\begin{array}{r}.0066 \\
. .110 \\
.913 \\
\end{array}$ & $\begin{array}{r}.159 \\
2.612 \\
.010 \\
\end{array}$ & $\mathrm{~N} / \mathrm{A}$ & $\begin{array}{r}.088 \\
. .893 \\
.375 \\
\end{array}$ \\
\hline $\begin{array}{l}\text { 24. This service is more conventicnl than driving } \\
\text { ourselves }\end{array}$ & $\begin{array}{r}.347 \\
7.440 \\
.000 \\
\end{array}$ & $\begin{array}{l}.030 \\
.510 \\
.611 \\
\end{array}$ & $\begin{array}{c}.142 \\
2.803 \\
.006 \\
\end{array}$ & $\begin{array}{r}.252 \\
3.357 \\
.001 \\
\end{array}$ \\
\hline 25. The connection with _ is convenient & N/A & $\overline{N / A}$ & $\begin{array}{r}.293 \\
5.229 \\
.000 \\
\end{array}$ & N/A \\
\hline DV: I sm very happy with this scrvice & $d d j \mathrm{R}^{2}=.945$ & $A d j R^{2}=.815$ & $\operatorname{Adj~R}^{j}=.749$ & $A d j \mathrm{R}^{\prime}=.821$ \\
\hline
\end{tabular}

samples is personal safety while on the transit vehicle. This is logical, as satisfaction represents a user's emotional reaction to the service they receive, and safety elicits a strongly emotional reaction in all service experiences. This directly underscores the importance of sending the message in the marketing efforts of public transit organizations. Specifically, it suggests that to be effective, the safety of niche marketing strategies must be communicated to potential users.

Analyzing the individual niche services, the university football shuttle users' satisfaction is enhanced if the service is perceived to be safe, clean, quick, and organized, enough information is provided about the service, convenient parking is available, and waiting time is minimal. The professional football shuttle users exhibit a similar pattern, except their satisfaction is less dependent on the cleanliness of the vehicle and more impacted by staff courtesy and staff and driver helpfulness. The summer metropolitan park shuttle service users also were more satisfied if they perceived the service to be safe, quick, and convenient; have adequate information available; have convenient parking; and if they felt the service was more convenient than driving. A unique consideration for this service was the connection with the area's mass 
transit system. Users who believed that connection to be convenient tended to be more satisfied. Users of the subscription vanpool were more satisfied if they perceived the service to be safe and well organized, the drivers helpful, tickets easy to buy, and if the service was perceived to be more convenient than driving.

\section{Importance of Individual Service Quality Perceptions}

A second consideration of note is the importance of the individual components of service quality perceptions. Given the influence of the service quality perceptions of the users of niche transit services, knowing the relative impact of each quality component allows more effective positioning and promotion decisions to be made. The results identified in Table 6 indicate that much of the variation in service quality perception is explained by the set of quality factors identified. In fact, 94.0, 79.0, 70.5, and 90.1 percent of the variation in the overall measure of performance excellence is explained by the composite set of factors in the four individual research samples.

For the university football shuttle users, service quality perceptions are most impacted by their evaluation of the cleanliness of vehicles, friendliness of staff, safety, freedom from fear of accidents, convenience of the service and parking, provision of information, and the organization of lines and the service in general. The professional football shuttle users equate service excellence with getting to destinations quickly, freedom from the fear of an accident, friendly staff, reasonable waiting times, organized services, good information, and convenient parking. The summer metropolitan park shuttle service riders use safety, the friendliness and courtesy of staff and drivers, and convenience to judge the quality of the service. Users of the subscription vanpool associated getting to destinations quickly, freedom of fear from accidents, organization of the service, friendliness and helpfulness of drivers, and convenience of the service with service quality excellence. 


\begin{tabular}{|c|c|c|c|c|}
\hline Variable & $\begin{array}{c}\text { Sample } 1 \\
\text { Beta } \\
\text { t-value } \\
\text { Significance }\end{array}$ & $\begin{array}{c}\text { Sample } 2 \\
\text { Beta } \\
\text { t-value } \\
\text { Significance }\end{array}$ & $\begin{array}{c}\text { Sample } 3 \\
\text { Beta } \\
\text { t-value } \\
\text { Significance }\end{array}$ & $\begin{array}{c}\text { Sample } 4 \\
\text { Beta } \\
\text { t-value } \\
\text { Significance }\end{array}$ \\
\hline 1. Our buses were very clean & $\begin{array}{r}.108 \\
2.544 \\
.012 \\
\end{array}$ & $\begin{array}{r}.045 \\
1.006 \\
.316 \\
\end{array}$ & $\begin{array}{l}.034 \\
.603 \\
.547 \\
\end{array}$ & $\begin{array}{r}.143 \\
2.779 \\
.007 \\
\end{array}$ \\
\hline 2. Our buses were comfortable & $\begin{array}{l}.022 \\
.440 \\
.661 \\
\end{array}$ & $\begin{array}{r}.063 \\
1.442 \\
.151 \\
\end{array}$ & $\begin{array}{l}.001 \\
.017 \\
.987 \\
\end{array}$ & $\begin{array}{r}.155 \\
2.602 \\
.011 \\
\end{array}$ \\
\hline 3. Our buses were not overly crowded & $\begin{array}{r}.047 \\
1.522 \\
.130 \\
\end{array}$ & $\begin{array}{l}.003 \\
.071 \\
.944 \\
\end{array}$ & $\begin{array}{l}.001 \\
.024 \\
.981\end{array}$ & $\begin{array}{r}.055 \\
.972 \\
.335 \\
\end{array}$ \\
\hline 4. We got to our destination quickly & $\begin{array}{r}.063 \\
1.578 \\
.130 \\
\end{array}$ & $\begin{array}{r}.132 \\
2.845 \\
.005 \\
\end{array}$ & $\begin{array}{l}.029 \\
.467 \\
.641 \\
\end{array}$ & $\begin{array}{r}.181 \\
3.195 \\
.002 \\
\end{array}$ \\
\hline 5. The ride was smooth & $\begin{array}{r}.042 \\
1.042 \\
.299 \\
\end{array}$ & $\begin{array}{l}.003 \\
.063 \\
.950 \\
\end{array}$ & $\begin{array}{l}.005 \\
.075 \\
.941 \\
\end{array}$ & $\begin{array}{r}.224 \\
3.241 \\
.002 \\
\end{array}$ \\
\hline 6. I had no lear that I would be in an accident & $\begin{array}{r}.067 \\
1.553 \\
.123 \\
\end{array}$ & $\begin{array}{r}.072 \\
1.654 \\
.100 \\
\end{array}$ & N/A & $\begin{array}{r}.096 \\
1.452 \\
.151 \\
\end{array}$ \\
\hline 7.1 lell safe while on the bus & $\begin{array}{r}.173 \\
4.137 \\
.000 \\
\end{array}$ & $\begin{array}{l}.014 \\
.310 \\
.757 \\
\end{array}$ & $\begin{array}{r}.243 \\
3.844 \\
.000 \\
\end{array}$ & $\begin{array}{l}.051 \\
.778 \\
.439 \\
\end{array}$ \\
\hline 8. The staff at the stops were courtoous & $\begin{array}{r}.098 \\
1.230 \\
.221 \\
\end{array}$ & $\begin{array}{l}.012 \\
.229 \\
.819 \\
\end{array}$ & $\begin{array}{r}.262 \\
4.377 \\
.000\end{array}$ & N/A \\
\hline 9. The stafr at the stops were friendly & $\begin{array}{r}.269 \\
3.742 \\
.000\end{array}$ & $\begin{array}{r}.093 \\
1.707 \\
.090\end{array}$ & $\begin{array}{r}.158 \\
2.011 \\
.046\end{array}$ & N/A \\
\hline $\begin{array}{l}\text { 10. The staff at the stops were very willing to } \\
\text { help riders }\end{array}$ & $\begin{array}{l}.097 \\
.988 \\
.325\end{array}$ & $\begin{array}{l}.018 \\
.351 \\
.726\end{array}$ & $\begin{array}{l}.001 \\
.005 \\
.996\end{array}$ & N/A \\
\hline $\begin{array}{l}\text { 11. Stall' were available at the stops when they } \\
\text { were needed }\end{array}$ & $\begin{array}{r}.396 \\
5.663 \\
.000 \\
\end{array}$ & $\begin{array}{r}.062 \\
1.264 \\
.208 \\
\end{array}$ & $\begin{array}{l}.027 \\
.293 \\
.770 \\
\end{array}$ & N/A \\
\hline 12. The locations of the stops were convenient & $\begin{array}{l}.034 \\
.830 \\
.408 \\
\end{array}$ & $\begin{array}{l}.000 \\
.005 \\
.996 \\
\end{array}$ & $\begin{array}{r}.045 \\
.662 \\
.509 \\
\end{array}$ & $\begin{array}{r}.084 \\
1.515 \\
.134 \\
\end{array}$ \\
\hline 13. I feli satic at the stops & $\begin{array}{r}.145 \\
2.653 \\
.009 \\
\end{array}$ & $\begin{array}{l}.026 \\
.490 \\
.625 \\
\end{array}$ & $\begin{array}{r}.135 \\
2.382 \\
.018 \\
\end{array}$ & $\begin{array}{l}.032 \\
.555 \\
.581 \\
\end{array}$ \\
\hline 14. The waiting time was reasonable & $\begin{array}{r}.086 \\
2.217 \\
.028\end{array}$ & $\begin{array}{r}.242 \\
5.404 \\
.000 \\
\end{array}$ & $\begin{array}{l}.051 \\
.742 \\
.459\end{array}$ & $\begin{array}{l}.008 \\
.125 \\
.901 \\
\end{array}$ \\
\hline 15. The lines to get on buses were well organized & $\begin{array}{r}.125 \\
2.921 \\
.004\end{array}$ & $\begin{array}{l}.054 \\
.980 \\
.329\end{array}$ & N/A & $\begin{array}{r}.246 \\
4.329 \\
.000\end{array}$ \\
\hline 16. Convenient parking was available & $\begin{array}{r}.194 \\
3.758 \\
.000\end{array}$ & $\begin{array}{l}.036 \\
.596 \\
.552 \\
\end{array}$ & $\begin{array}{l}.001 \\
.009 \\
.993\end{array}$ & $\begin{array}{l}.044 \\
.739 \\
.463 \\
\end{array}$ \\
\hline 17. The drivers were courteous & $\begin{array}{l}.035 \\
.060 \\
.510\end{array}$ & $\begin{array}{r}.170 \\
3.849 \\
.000\end{array}$ & $\begin{array}{r}.575 \\
5.094 \\
.000\end{array}$ & $\begin{array}{l}.016 \\
.215 \\
.830\end{array}$ \\
\hline 18. The drivers were friendly & $\begin{array}{r}.052 \\
1.054 \\
.294\end{array}$ & $\begin{array}{r}.114 \\
1.239 \\
.217\end{array}$ & $\begin{array}{r}.458 \\
3.768 \\
.000 \\
\end{array}$ & $\begin{array}{r}.123 \\
1.642 \\
.105 \\
\end{array}$ \\
\hline 19. The drivers were very willing to help riders & $\begin{array}{r}.071 \\
1.447 \\
.150\end{array}$ & $\begin{array}{r}.100 \\
1.463 \\
.145\end{array}$ & $\begin{array}{l}.023 \\
.226 \\
.882\end{array}$ & $\begin{array}{r}.243 \\
4.295 \\
.000\end{array}$ \\
\hline 20. It was easy to buy a ticket & $\begin{array}{r}.151 \\
2.706 \\
.008\end{array}$ & $\begin{array}{r}.089 \\
1.483 \\
.140\end{array}$ & $\begin{array}{l}.028 \\
.362 \\
.718 \\
\end{array}$ & $\begin{array}{r}.082 \\
1.285 \\
.203\end{array}$ \\
\hline 21. We were well organized & $\begin{array}{r}.322 \\
4.365 \\
000\end{array}$ & $\begin{array}{r}.266 \\
5.002 \\
000\end{array}$ & $\mathbf{N} / \mathbf{A}$ & $\begin{array}{r}.173 \\
2.158 \\
.035\end{array}$ \\
\hline 22. Enough inlormation was avaitable & $\begin{array}{r}.327 \\
6.910 \\
.000\end{array}$ & $\begin{array}{r}.109 \\
1.709 \\
.089\end{array}$ & $\begin{array}{r}.076 \\
1.197 \\
.233 \\
\end{array}$ & $\begin{array}{l}.056 \\
.598 \\
.552 \\
\end{array}$ \\
\hline
\end{tabular}




\begin{tabular}{|c|c|c|c|c|}
\hline \multicolumn{5}{|c|}{ Table 6 (continued) } \\
\hline Variable & $\begin{array}{c}\text { Sample I } \\
\text { Beta } \\
\text { t-value } \\
\text { Significance }\end{array}$ & $\begin{array}{c}\text { Sample } 2 \\
\text { Beta } \\
\text { t-value } \\
\text { Significance }\end{array}$ & $\begin{array}{c}\text { Sample } 3 \\
\text { Beta } \\
\text { t-value } \\
\text { Significance }\end{array}$ & $\begin{array}{c}\text { Sample } 4 \\
\text { Beta } \\
\text { t-value } \\
\text { Significance }\end{array}$ \\
\hline 23. Convenient parking was available & $\begin{array}{l}.107 \\
1.624 \\
.107\end{array}$ & $\begin{array}{r}.173 \\
3.630 \\
.000 \\
\end{array}$ & N/A & $\begin{array}{l}.013 \\
.162 \\
.872 \\
\end{array}$ \\
\hline $\begin{array}{l}\text { 24. This service is more convenient than driving } \\
\text { ourselves }\end{array}$ & $\begin{array}{r}.419 \\
7.758 \\
.090 \\
\end{array}$ & $\begin{array}{r}.1 .41 \\
3.101 \\
.002 \\
\end{array}$ & $\begin{array}{r}.167 \\
3.040 \\
.003 \\
\end{array}$ & $\begin{array}{r}.386 \\
6.859 \\
.000 \\
\end{array}$ \\
\hline 25. The connection with __ is convenient & $\mathrm{N} / \mathrm{A}$ & $N / A$ & $\begin{array}{l}.043 \\
.321 \\
.748\end{array}$ & $N / \Lambda$ \\
\hline $\begin{array}{l}\text { DV: The quality of the service I received loday } \\
\text { was excelient }\end{array}$ & $A d j \mathrm{R}=.940$ & $1 d j R^{2}=.790$ & $\operatorname{ddj} \mathrm{R}^{2}=.70 \mathrm{~S}$ & $A d j R^{\prime}=.9101$ \\
\hline
\end{tabular}

\section{Conclusions and Implications}

The study presented clearly suggests that niche public transit marketing strategies can be effective tools in public transit's efforts to attract and retain new riders. Whereas some might look at niche efforts, such as the ones investigated, as extravagant and superfluous, they, in fact, are one of the most effective ways to reach new markets. Much of today's consumer decision making is emotionally derived from individuals' satisfaction with their purchase experiences. Sporting events, holiday celebrations, and vacation excursions are occasions packed with positive emotions. If public transit is able to tap into these emotions by providing convenient and attractive alternatives to dull commutes and harried searches for parking, these experiences can place public transit in the evoked set for other dayto-day work and pleasure commutes. As such, niche strategies can represent a marketing investment; albeit, one that often is also profitable in its own right.

Interestingly, the results of this investigation suggest that consumers' decisions relative to the use of public transit move beyond the role of clean, attractive, and safe vehicles and friendly, courteous staff and drivers. They also move beyond issues of personal safety, either while on vehicles or at stops. This is not to suggest that these issues are not important determinants of public transit users' service quality perceptions; satisfaction with the service; or their intention to reuse the niche service, use other transit services, or to recommend the transit agency to a friend. They are important considerations in each of these 
areas. However, the transit industry has known that for years.

Equally interesting is the important role in these decisions assigned by niche public transit users to the organization of the service, the provision of information about the service, and the ease of gaining access to the service (i.e., buying tickets, waiting time, and parking). Study respondents were largely nontransit users. One might surmise from the results that they are more likely to use a service if it appears organized, if they have sufficient information to make its use convenient, and if access to the service is assured. These aspects should be incorporated into the design and promotion of transit services intended to attract and retain new users.

In conclusion, the declining trend in public transit's share of riders does not reflect a decaying market for the industry's services. Rather it appears to be signaling a need for a redirection of public transit product planning. Gone are the days when a significant number of U.S. consumers had no other means of transportation. The public transit market in the United States is now a discretionary market. The potential public transit users today have options available to them. While it is true that traditional transportation patterns have been altered and many commutes now represent multiple-purpose trips, this does not alter the fact that there is still a legitimate need for public transit services in this market. It is the responsibility of the transit industry to identify that role and to adjust its product offerings to reflect the market's needs. The market will not change.

In order for public transit to gain a larger share of the people-moving market, its marketers need to gain a better understanding of what motivates individuals to make specific transit choices. Niche markets are one area where public transit has many documented successes. Perhaps, in this industry, learning from one's positive experiences is as important, if not more so, than learning from its mistakes. 


\section{References}

Ball, W. 1994. Commuting alternatives in the United States: Recent trends and a look to the future. Washington, DC: Office of University Research and Education, Research and Special Programs Administration, DOT-T-95-11.

Blattberg, Robert C., and Scott A. Neslin. 1990. Sales promotion. Englewood Cliffs, NJ: Prentice-Hall.

Boulding, William, Eunkyu Lee, and Richard Staelin. 1992. The long-term differentiation value of marketing communication actions. Marketing Science Institute: 92-133.

Jones, John P. September/October 1990. The double jeopardy of sales promotions. Harvard Business Review 145-52.

Kemp, Michael A., Mark Kiefer, James Marca, Mark Hickman, Stephen Keen, Nino Campitelli, and Donald Cleghorn. 1997. Building transit ridership: An exploration of transit's market share and the public policies that influence it. Washington, DC: Prepared for the Transit Cooperative Research Program, Report 27, TCRP H-4A.

Khattak, Asad J., Hisham Noeimi, and Haitham M. Al-Deek. Fall 1996. A taxonomy for advanced public transportation systems. Journal of Public Transportation 1(1): 39-64.

Langlois, Richard N., ed. 1986. Economics as a process. Cambridge, England: Cambridge University Press.

Pisarski, A. 1992. Travel behavior issues in the 90's. Washington, DC: Prepared for the Office of Highway Information and Management, HPM40, USDOT, FHWA. 


\section{About the Authors}

J. JoSEPH CRONIN, JR. (jcronin@cob.fsu.edu) is a professor of marketing and director of Education and Training for the Marketing Institute at Florida State University. Dr. Cronin's primary research interests are in the areas of service quality and customer satisfaction, particularly as applied to sports, public transit, and managed health care issues. Dr. Cronin received his Ph.D. in marketing and logistics from Ohio State University.

Roscoe Hightower (roscoe.hightower@famu.edu) is an assistant professor of marketing at Florida A\&M University. He received his Ph.D. in marketing from Florida State University.

MiChaEL K. BRAdy (bradym@bc.edu) is an assistant professor of marketing at the W. E. Carroll School of Management at Boston College. He received his Ph.D. in marketing from Florida State University. 